\title{
An Analysis of Students Motivation in Online Learning Based on Realistic Mathematical Comic Videos
}

\author{
Tetty Natalia Sipayung ${ }^{1}$, Sinta Dameria Simanjuntak ${ }^{2}$, Ariyadi Wijaya ${ }^{3}$, Sugiman $^{4}$ \\ 1,2 Department of Mathematics Education, Catholic University of Saint Thomas, Indonesia \\ 3,42Department of Mathematics Education, State University of Yogyakarta, Indonesia \\ tetty_sipayung@ust.ac.id
}

\begin{abstract}
In this era of revolution 4.0, it is hoped that everyone will be active in managing their knowledge through digital media. Digital media needs to be well designed attractive. This can have an impact on motivation and learning outcomes, especially in the field of education. In online learning, digital media is an alternative in helping the learning process. Therefore a qualitative research was conducted. The subjects of this study were seventh grade students of SMP HKBP Lubuk Pakam for the 2020/2021 Academic Year who applied online learning assisted by realistic mathematics comic videos. While the object of this study is learning motivation so that the purpose of this study to analyze the learning motivation of these students. Based on the results of the provision of a learning motivation questionnaire, it was found that the average learning motivation of students who were taught using realistic mathematics comic videos in online learning was high which was assessed based on six indicators, namely responsibility, trying to excel, liking challenges, independence, fortitude, and resilience. This is a positive attitude that supports efforts to improve learning outcomes, especially in online learning.
\end{abstract}

Keywords

motivation; online learning, comic videa, realistic mathematics

\section{Introduction}

Mathematics is one of the main subjects in the field of school education. In addition, mathematics is a science that is also needed is solving problems of everyday life. Mathematics cannot be separated from problems (Ulya, H., Kartono, and A. Retnoningsih, 2014: 577). By mastering mathematics at least helps in solving problems. Mathematics is related to thinking skills. Mathematics is a systematic way of thinking that creates solutions to real-world problems by modeling (Özdemira, Emine and Devrim Üzela, 2012: 1207). Freudenthal considered mathematics as a human activity. Therefore, according to him, mathematics should not be studied as a closed system but as an activity of mathematical reality and, if possible, even dememize mathematics (Panhuizen, Marja Van den Heuvel and Paul Drijvers. 2014: 522).

The Freudenthal Institute in the Netherlands develops teaching and learning theory in mathematics education, namely realistic mathematics education (RME). In the RME concept, mathematics is a human activity and must be connected with reality (Laras Lestaria and Edy Surya, 2017: 92).

Education is one way to produce quality Human Resources (HR) with experience changes in knowledge, skills and attitudes. These changes can be a capital to improve selfcompetence in facing the era of globalization that always undergo the change (Sitorus et al, 2019). Education that is carried out from time to time is always changing in accordance with the times. Therefore, teachers as learning managers are required to be more creative and innovative in order to make learning outcomes more optimal. This is in accordance with 
the Law of the Republic of Indonesia Number 20 of 2003, Article 1 paragraph 19, concerning the National Education System (Sisdiknas) that education is a conscious and planned effort to realize a learning atmosphere and learning process so that students actively develop their potential to have spiritual, religious, self-control, personality, intelligence, noble character, and skills needed by themselves, society, nation and state (Simorangkir and Sembiring, 2018).

When viewed from the results of learning mathematics, it still shows concerning results. This can be concluded based on the 2018 PISA data. Indonesian children's math abilities score 379 , which is ranked 72 out of 78 countries. In fact, it has decreased compared to the previous PISA results. This is certainly not a proud achievement but it is a cause for concern. One of the causes of low student learning outcomes is because many students consider mathematics to be difficult to learn and the characteristics of mathematic are abstract, making mathematics a frightening specter for students (Nopriani Lubis, Jumaita, et al., 2017: 131).

Going through the revolutionary era 4.0 required changes in the field of education in particular. The current mediated reality and development of user generated online content have introduced various measures for publishing and accessing instructional resources. Educators are encouraged to take advantage of these contemporary modalities to engage today's digital learners (Buzzetto-More, Nicole. 2015: 55). Teachers must strive to improve the ability to apply ICT in learning. This can bring an increase in student motivation. According to Azhar (2018) motivation is a condition that is contained in someone who encourages to do a certain activity in order to achieve a goal. Therefore, teachers must strive to be able to carry out online learning in addition to offline learning.

One of the tools that can be used in online learning is video learning. Video-based learning is a powerful resource in online teaching (Ahmed Mohamed Fahmy Yousef, Mohamed Amine Chatti, Ulrik Schroeder, 2014: 122). The term video-based learning refers to electronic technology that takes and distributes educational images that display moving scenes (Beheshti, Mobina., Et. Al. 2018: 62). Videos can be used in a number of ways to successfully support various teaching strategies (Michael Carmichael, 7). The use of videos can facilitate students in more interesting learning activities because students get different learning experiences, but if implemented by the teacher effectively (Hadijah, Sitti. 2016: 307). Material-based videos increase creativity and collaboration (Gia Lenn L. Mendoza, et al., 2015: 81). Comic videos can be designed to be videos based on learning materials. Comic stories are interesting topics that are familiar to children which can increase motivation and make students learn easier (Georgaka, Angeliki Deligianni and Ourania Pouroutidi, 2016: 234). Comics allow students to learn not only with text but also with pictures (Dwi Arinii, Fitri, Abdul Salim Choiri, and Sunardi, 2017: 73). Comics are considered effective and efficient in improving the quality and effectiveness of learning (Lestari, Witri and Yhohan Ady Chandra, 2018: 55).

Based on the explanation above, the authors conducted a qualitative study to analyze student learning motivation. In this case, students who were taught with realistic mathematics comic videos in online learning were analyzed their learning motivation.

\section{Reseach Methods}

This research is a qualitative research with a descriptive method with a quantitative approach. The purpose of this study is to analyze the learning motivation of students who are taught using realistic mathematics comic videos in online learning. The subjects of this study were 32 grade VII students of SMP HKBP Lubuk Pakam for the 2020/2021 academic 
year. While the object of this study is to analyze student learning motivation. This research procedure includes: (1). Determine the research topic; (2). Determine the focus of the research question; (3) Determine the subject and object of research; (4) Develop a research plan; (5) Collecting data; (6) Data Interpretation; and (7) Report preparation.

This study used a learning motivation questionnaire as a data collection instrument. The questionnaire is arranged based on six indicators of learning motivation which include (1) responsibility; (2) trying to excel; (3) likes challenges; (4) independence; (5) fortitude; and (6) tenacity. The learning motivation questionnaire lattice used in this study can be seen in the following table:

Table 1. Students' Learning Motivation Questionnaire Grid

\begin{tabular}{|c|l|c|c|c|}
\hline \multirow{2}{*}{ No. } & \multirow{2}{*}{ Indicator } & \multicolumn{2}{|c|}{ Questionnaire Item Number } & \multirow{2}{*}{ amount } \\
\cline { 3 - 4 } & & $\begin{array}{c}\text { Positive } \\
\text { Statement }\end{array}$ & $\begin{array}{c}\text { Negative } \\
\text { Statements }\end{array}$ & \\
\hline 1. & Responsible & $1,4,10,18,29$ & $11,12,14$ & 8 \\
\hline 2. & Trying to excel & $6,19,28$ & 2,5 & 5 \\
\hline 3. & Love a challenge & $20,21,23,25$ & $15,16,24$ & 7 \\
\hline 4. & Independence & $7,26,27$ & 13 & 4 \\
\hline 5. & Fortitude & 9 & $8,17,22$ & 4 \\
\hline 6. & Tenacity & 3,30 & - & 2 \\
\hline & Amount & 18 & 12 & 30 \\
\hline
\end{tabular}

As an interpretation of the percentage of the results of the student motivation questionnaire according to Suhasimi Arikunto (in Muladi, S., 2015: 6) can be seen in the following table:

Table 2. Percentage Interpretation of Learning Motivation

\begin{tabular}{|c|c|}
\hline $\begin{array}{c}\text { Percentage Range of } \\
\text { Learning Motivation }\end{array}$ & Category \\
\hline $80<\mathrm{P} \leq 100$ & Very high \\
\hline $65<\mathrm{P} \leq 80$ & High \\
\hline $55<\mathrm{P} \leq 65$ & Moderate \\
\hline $40<\mathrm{P} \leq 55$ & Low \\
\hline $\mathrm{P} \leq 40$ & Very low \\
\hline
\end{tabular}

The average percentage per indicator of learning motivation using the formula:

$$
\text { Percentage }=\frac{\text { number of aspect indicator score to }-i}{\text { maximum score of the aspect indicator to }-i} \times 100 \%
$$

\section{Results and Discussion}

In the odd semester of the 2020/2021 academic year, online mathematics learning was carried out at SMP HKBP Lubuk Pakam. Learning is carried out using the WhatsApp application and applying learning with a realistic mathematical approach. Before the learning was carried out, students were divided into several study discussion groups. During the learning process, the teacher distributed a realistic mathematics comic video for discussion and then continued giving Student Activity Sheets to discuss while the learning 
took place, then a video summary of the material explanation was distributed. After the implementation of learning was carried out several meetings, qualitative research was carried out with the aim of analyzing learning motivation. In the implementation of the research, data was collected using a learning motivation questionnaire. The percentage data of each item of learning motivation on the responsibility indicator can be seen in the following table:

Table 3. The percentage of each item of student learning motivation on indicator 1

\begin{tabular}{|c|c|c|c|c|c|c|c|c|c|c|c|}
\hline \multicolumn{2}{|c|}{$\begin{array}{c}\text { No. } \\
\text { Item }\end{array}$} & \multicolumn{2}{|c|}{$\begin{array}{c}\text { Strongly } \\
\text { Agree }\end{array}$} & \multicolumn{2}{|c|}{ Agree } & \multicolumn{2}{|c|}{ Disagree less } & \multicolumn{2}{|c|}{ Disagree } & \multicolumn{2}{|c|}{$\begin{array}{l}\text { Strongly } \\
\text { Disagree }\end{array}$} \\
\hline$(+)$ & $(-)$ & Frequency & $\%$ & Frequency & $\%$ & Frequency & $\%$ & Frequency & $\%$ & Frequency & $\%$ \\
\hline 1 & & 13 & 40,6 & 16 & 50 & 3 & 9,4 & 0 & 0 & 0 & 0 \\
\hline 4 & & 12 & 37,5 & 15 & 46,9 & 4 & 12,5 & 1 & 3,1 & 0 & 0 \\
\hline 10 & & 11 & 34,4 & 15 & 46,9 & 5 & 15,6 & 0 & 0 & 1 & 3,1 \\
\hline 18 & & 13 & 40,6 & 15 & 46,9 & 2 & 6,3 & 1 & 3,1 & 1 & 3,1 \\
\hline 29 & & 12 & 37,5 & 18 & 56,2 & 2 & 6,3 & 0 & 0 & 0 & 0 \\
\hline & 11 & 0 & 0 & 0 & 0 & 6 & 18,8 & 9 & 28,1 & 17 & 53,1 \\
\hline & 12 & 0 & 0 & 2 & 6,3 & 4 & 12,5 & 18 & 56,2 & 8 & 25 \\
\hline & 14 & 0 & 0 & 1 & 3,1 & 6 & 18,8 & 15 & 46,9 & 10 & 31,2 \\
\hline \multicolumn{2}{|c|}{ Amount } & 61 & 190,6 & 82 & 256,3 & 32 & 100,2 & 44 & 137,4 & 37 & 115,5 \\
\hline \multicolumn{2}{|c|}{ Average } & & 23,82 & & 32,04 & & 12,52 & & 17,18 & & 14,44 \\
\hline
\end{tabular}

Based on the table above, it is known that the average student who stated strongly agree was $23.82 \%$, students who agreed to $32.04 \%$, students who disagreed $12.52 \%$, students who disagreed $17.18 \%$ and There were $14.44 \%$ students who strongly disagreed.The percentage of student learning motivation on the responsibility indicator can be seen in the following table:

Table 4. Percentage of Learning Motivation on Indicator 1

\begin{tabular}{|c|c|c|c|c|}
\hline Item Number & Score & Frequency & Total Score & Percentage (\%) \\
\hline \multirow{5}{*}{$\begin{array}{c}1,4,10,11,12 \\
14,18,29\end{array}$} & 5 & 96 & 480 & 44,8 \\
\hline & 4 & 121 & 484 & 45,1 \\
\hline & 3 & 32 & 96 & 9 \\
\hline & 2 & 5 & 10 & 0,9 \\
\hline & 1 & 2 & 2 & 0,2 \\
\hline \multicolumn{2}{|c|}{ Total } & 256 & 1,072 & 100 \\
\hline \multicolumn{2}{|c|}{ Highest Score } & \multicolumn{3}{|c|}{5} \\
\hline \multicolumn{2}{|c|}{ Number of Statement } & \multicolumn{3}{|c|}{8} \\
\hline \multicolumn{2}{|c|}{ Number of Respondents } & \multicolumn{3}{|c|}{32} \\
\hline \multicolumn{2}{|c|}{ Maximum Score } & \multicolumn{3}{|c|}{1.280} \\
\hline \multicolumn{2}{|c|}{ Percent Average } & \multicolumn{3}{|c|}{83,75} \\
\hline
\end{tabular}

In the table above, it is known that the average percentage of learning motivation on responsible indicators is $83.75 \%$. The percentage of each item of learning motivation on the indicators of trying to excel can be seen in the following table: 
Table 5. Percentage of Each Learning Motivation Item in Indicator 2

\begin{tabular}{|c|c|c|c|c|c|c|c|c|c|c|c|}
\hline \multicolumn{2}{|c|}{\begin{tabular}{|c|} 
No. \\
Item
\end{tabular}} & \multicolumn{2}{|c|}{$\begin{array}{c}\text { Strongly } \\
\text { agree }\end{array}$} & \multicolumn{2}{|c|}{ Agree } & \multicolumn{2}{|c|}{ Disagree less } & \multicolumn{2}{|c|}{ Disagree } & \multicolumn{2}{|c|}{$\begin{array}{l}\text { Strongly } \\
\text { Disagree }\end{array}$} \\
\hline$(+)$ & $(-)$ & Frequency & $\%$ & Frequency & $\%$ & Frequency & $\%$ & Frequency & $\%$ & Frequency & $\%$ \\
\hline 6 & & 20 & 62,5 & 10 & 31,2 & 2 & 6,3 & 0 & 0 & 0 & 0 \\
\hline 19 & & 7 & 21,9 & 19 & 59,4 & 5 & 15,6 & 1 & 3,1 & 0 & 0 \\
\hline 28 & & 15 & 46,9 & 15 & 46,9 & 1 & 3,1 & 1 & 3,1 & 0 & 0 \\
\hline & 2 & 7 & 21,9 & 9 & 28,1 & 7 & 21,9 & 9 & 28,1 & 0 & 0 \\
\hline & 5 & 8 & 25 & 7 & 21,9 & 7 & 21,9 & 8 & 25 & 2 & 6,2 \\
\hline \multicolumn{2}{|c|}{ Amount } & 57 & 178,2 & 60 & 187,5 & 22 & 68,8 & 19 & $\begin{array}{c}59, \\
3\end{array}$ & 2 & 6,2 \\
\hline \multicolumn{2}{|c|}{ Average } & & 35,64 & & 37,50 & & 13,76 & & 11,86 & & 1,24 \\
\hline
\end{tabular}

Based on the table above, it is known that on average there were $35.64 \%$ of students who stated strongly agree, $37.50 \%$ of students who agreed, $13.76 \%$ of students who disagreed, $11.18 \%$ and $11.18 \%$ of students who disagreed There were $1.24 \%$ students who strongly disagreed. The percentage of student learning motivation on the indicators of trying to excel can be seen in the following table:

Table 6. Percentage of Learning Motivation on Indicator 2

\begin{tabular}{|c|c|c|c|c|}
\hline Item Number & Score & Frequency & Total Score & Percentage $(\%)$ \\
\hline \multirow{5}{*}{$2,5,6,19,28$} & 5 & 44 & 220 & 37,9 \\
\hline & 4 & 61 & 244 & 42 \\
\hline & 3 & 22 & 66 & 11,3 \\
\hline & 2 & 18 & 36 & 6,2 \\
\hline & 1 & 15 & 15 & 2,6 \\
\hline \multicolumn{2}{|c|}{ Total } & 160 & 581 & 100 \\
\hline \multicolumn{2}{|c|}{ Highest Score } & \multicolumn{3}{|c|}{5} \\
\hline \multicolumn{2}{|c|}{ Number of Statement } & \multicolumn{3}{|c|}{5} \\
\hline \multicolumn{2}{|c|}{ Number of Respondents } & \multicolumn{3}{|c|}{32} \\
\hline \multicolumn{2}{|c|}{ Maximum Score } & \multicolumn{3}{|c|}{800} \\
\hline \multicolumn{2}{|c|}{ Percent Average } & \multicolumn{3}{|c|}{72,63} \\
\hline
\end{tabular}

In the table above, it is known that the average percentage of learning motivation on the indicators of trying to excel is $72.63 \%$. The percentage of each learning motivation item on the like a challenge indicator can be seen in the following table:

Table 7. Percentage of Each Learning Motivation Item in Indicator 3

\begin{tabular}{|c|c|c|c|c|c|c|c|c|c|c|c|}
\hline \multicolumn{2}{|c|}{$\begin{array}{l}\text { No. } \\
\text { Item }\end{array}$} & \multicolumn{2}{|c|}{$\begin{array}{c}\text { Strongly } \\
\text { agree }\end{array}$} & \multicolumn{2}{|c|}{ Agree } & \multicolumn{2}{|c|}{$\begin{array}{c}\text { Disagree } \\
\text { less }\end{array}$} & \multicolumn{2}{|c|}{ Disagree } & \multicolumn{2}{|c|}{$\begin{array}{l}\text { Strongly } \\
\text { Disagree }\end{array}$} \\
\hline$(+)$ & $(-)$ & Frequency & $\%$ & Frequency & $\%$ & $(+)$ & $(-)$ & Frequency & $\%$ & Frequency & $\%$ \\
\hline 20 & & 2 & 6,3 & 10 & 31,2 & 11 & 34,4 & 7 & 21,9 & 2 & 6,2 \\
\hline 21 & & 10 & 31,2 & 20 & 62,5 & 0 & 0 & 2 & 6,2 & 0 & 0 \\
\hline 23 & & 7 & 21,9 & 17 & 53,1 & 6 & 18,7 & 2 & 6,2 & 0 & 0 \\
\hline 25 & & 8 & 25 & 15 & 46,9 & 7 & 21,9 & 1 & 3,1 & 1 & 3,1 \\
\hline & 15 & 0 & 0 & 3 & 9,4 & 9 & 28,1 & 10 & 31,2 & 10 & 31,2 \\
\hline & 16 & 0 & 0 & 2 & 6,2 & 12 & 37,5 & 13 & 40,6 & 5 & 15,6 \\
\hline & 24 & 5 & 15,6 & 16 & 50 & 6 & 18,7 & 5 & 15,6 & 0 & 0 \\
\hline
\end{tabular}




\begin{tabular}{|c|c|c|c|c|c|c|c|c|c|c|}
\hline Amount & 32 & 100 & 83 & 259,3 & 51 & 159,3 & 40 & 124,8 & 18 & 56,1 \\
\hline Average & & 14,29 & & 37,04 & & 22,76 & & 17,83 & & 8,01 \\
\hline
\end{tabular}

Based on the table above, it is known that the average student who stated strongly agree was $14.29 \%$, students who agreed $37.04 \%$, students who disagreed $22.76 \%$, students who disagreed $17.83 \%$ and students who strongly disagreed were $8.01 \%$. The percentage of student learning motivation on indicators of liking challenges can be seen in the following table:

Table 8. Percentage of Learning Motivation on Indicator 3

\begin{tabular}{|c|c|c|c|c|}
\hline Item Number & Score & Frequency & Total Score & Percentage (\%) \\
\hline \multirow{5}{*}{$\begin{array}{c}15,16,20,21 \\
23,24,25\end{array}$} & 5 & 42 & 210 & 26,4 \\
\hline & 4 & 90 & 360 & 45,2 \\
\hline & 3 & 51 & 153 & 19,2 \\
\hline & 2 & 33 & 66 & 8,3 \\
\hline & 1 & 7 & 7 & 0,9 \\
\hline \multicolumn{2}{|c|}{ Total } & 223 & 796 & 100 \\
\hline \multicolumn{2}{|c|}{ Highest Score } & \multicolumn{3}{|c|}{5} \\
\hline \multicolumn{2}{|c|}{ Number of Statement } & \multicolumn{3}{|c|}{7} \\
\hline \multicolumn{2}{|c|}{ Number of Respondents } & \multicolumn{3}{|c|}{32} \\
\hline \multicolumn{2}{|c|}{ Maximum Score } & \multicolumn{3}{|c|}{1.120} \\
\hline \multicolumn{2}{|c|}{ Percent Average } & \multicolumn{3}{|c|}{71,07} \\
\hline
\end{tabular}

In the table above, it is known that the average percentage of learning motivation on the indicators of trying to excel is $71.07 \%$. The percentage of each item of learning motivation on the independence indicator can be seen in the following table:

Table 9. Percentage of Each Learning Motivation Item in Indicator 4

\begin{tabular}{|c|c|c|c|c|c|c|c|c|c|c|c|}
\hline \multicolumn{2}{|c|}{$\begin{array}{l}\text { No. } \\
\text { Item }\end{array}$} & \multicolumn{2}{|c|}{ Strongly agree } & \multicolumn{2}{|c|}{ Agree } & \multicolumn{2}{|c|}{$\begin{array}{c}\text { Disagree } \\
\text { less }\end{array}$} & \multicolumn{2}{|c|}{ Disagree } & \multicolumn{2}{|c|}{$\begin{array}{l}\text { Strongly } \\
\text { Disagree }\end{array}$} \\
\hline$(+)$ & $(-)$ & Frequency & $\%$ & Frequency & $\%$ & $(+)$ & $(-)$ & Frequency & $\%$ & requency & $\%$ \\
\hline 7 & & 8 & 25 & 14 & 43,7 & 7 & 21,9 & 2 & 6,2 & 1 & 3,1 \\
\hline 26 & & 10 & 31,2 & 19 & 59,4 & 2 & 6,3 & 1 & 3,1 & 0 & 0 \\
\hline 27 & & 6 & 18,7 & 23 & 71,9 & 1 & 3,1 & 2 & 6,2 & 0 & 0 \\
\hline & 13 & 3 & 9,4 & 8 & 25 & 6 & 18,7 & 7 & 21,9 & 8 & 25 \\
\hline $\mathrm{Am}$ & ount & 27 & 84,3 & 64 & 200 & 16 & 50 & 12 & 37,4 & 9 & 28,1 \\
\hline Ave & rage & & 21,08 & & 50 & & 12,50 & & 9,40 & & 7,02 \\
\hline
\end{tabular}

Based on the table above, it is known that the average student who strongly agreed was $21.08 \%$, students who agreed to $50 \%$, students who disagreed $12.50 \%$, students who disagreed $9.40 \%$ and students who disagreed Strongly disagree there is $7.02 \%$. The percentage of student learning motivation on the independence indicator can be seen in the following table: 
Table 10. Percentage of Learning Motivation on Indicator 4

\begin{tabular}{|c|c|c|c|c|}
\hline Item Number & Score & Frequency & Total Score & Percentage (\%) \\
\hline \multirow{4}{*}{$7,13,26,27$} & 5 & 32 & 160 & 32.7 \\
\cline { 2 - 5 } & 4 & 63 & 252 & 51.4 \\
\cline { 2 - 5 } & 3 & 16 & 48 & 9.8 \\
\cline { 2 - 5 } & 2 & 13 & 26 & 5.3 \\
\cline { 2 - 5 } & 1 & 4 & 4 & 0.8 \\
\hline Total & 128 & 490 & 100 \\
\hline Highest Score & \multicolumn{4}{|c|}{5} \\
\hline Number of Statement & \multicolumn{4}{|c|}{640} \\
\hline Number of Respondents & \multicolumn{4}{|c|}{76,56} \\
\hline Maximum Score & \multicolumn{4}{|c}{} \\
\hline \multicolumn{2}{|c|}{ Percent Average } & \multicolumn{4}{|c|}{} \\
\hline
\end{tabular}

In the table above, it is known that the average percentage of learning motivation on the indicators of trying to excel is $71.07 \%$. The percentage of each item of learning motivation on the grit indicators can be seen in the following table:

Table 11. Percentage of Each Learning Motivation Item in Indicator 5

\begin{tabular}{|c|c|c|c|c|c|c|c|c|c|c|c|}
\hline \multicolumn{2}{|c|}{$\begin{array}{c}\text { No. } \\
\text { Item }\end{array}$} & \multicolumn{2}{|c|}{$\begin{array}{c}\text { Strongly } \\
\text { agree }\end{array}$} & \multicolumn{2}{|c|}{ Agree } & \multicolumn{2}{|c|}{$\begin{array}{l}\text { Disagree } \\
\text { less }\end{array}$} & \multicolumn{2}{|c|}{ Disagree } & \multicolumn{2}{|c|}{$\begin{array}{l}\text { Strongly } \\
\text { Disagree }\end{array}$} \\
\hline$(+)$ & $(-)$ & Frequency & $\%$ & Frequency & $\%$ & $(+)$ & $(-)$ & Frequency & $\%$ & Frequency & $\%$ \\
\hline 9 & & 16 & 50 & 15 & 46,9 & 0 & 0 & 0 & 0 & 1 & 3,1 \\
\hline & 8 & 0 & 0 & 2 & 6,3 & 7 & 21,9 & 14 & 43,7 & 9 & 28,1 \\
\hline & 17 & 0 & 0 & 5 & 15,6 & 10 & 31,3 & 12 & 37,5 & 5 & 15,6 \\
\hline & 22 & 0 & 0 & 2 & 6,3 & 10 & 31,3 & 13 & 40,6 & 7 & 21,9 \\
\hline & & 16 & 50 & 24 & 75,1 & 27 & 84,5 & 39 & 121,8 & 22 & 68,7 \\
\hline Ave & ge & & 12,5 & & 18,76 & & 21,12 & & 30,45 & & 17,17 \\
\hline
\end{tabular}

Based on the table above, it is known that the average student who stated strongly agree was $12.50 \%$, students who agreed to $18.76 \%$, students who disagreed $21.12 \%$, students who disagreed $30.45 \%$ and students who strongly disagreed were $17.17 \%$. The percentage of student learning motivation on the grit indicators can be seen in the following table:

Table 12. Percentage of Learning Motivation on Indicator 5

\begin{tabular}{|c|c|c|c|c|}
\hline Item Number & Score & Frequency & Total Score & Percentage $(\%)$ \\
\hline \multirow{5}{*}{$8,9,17,22$} & 5 & 37 & 185 & 42 \\
\hline & 4 & 39 & 156 & 35.5 \\
\hline & 3 & 27 & 81 & 18.4 \\
\hline & 2 & 9 & 18 & 4,1 \\
\hline & 1 & 0 & 0 & 0 \\
\hline \multicolumn{2}{|c|}{ Total } & 112 & 440 & 100 \\
\hline \multicolumn{2}{|c|}{ Highest Score } & \multicolumn{3}{|c|}{5} \\
\hline \multicolumn{2}{|c|}{ Number of Statement } & \multicolumn{3}{|c|}{4} \\
\hline \multicolumn{2}{|c|}{ Number of Respondents } & \multicolumn{3}{|c|}{32} \\
\hline \multicolumn{2}{|c|}{ Maximum Score } & \multicolumn{3}{|c|}{640} \\
\hline \multicolumn{2}{|c|}{ Percent Average } & \multicolumn{3}{|c|}{68,75} \\
\hline
\end{tabular}


In the table above, it is known that the average percentage of learning motivation on the indicators of trying to excel is $71.07 \%$. The percentage of each item of learning motivation on the resilience indicator can be seen in the following table:

Table 13. Percentage of Each Learning Motivation Item in Indicator 6

\begin{tabular}{|c|c|c|c|c|c|c|c|c|c|c|c|}
\hline \multicolumn{2}{|c|}{$\begin{array}{l}\text { No. } \\
\text { Item }\end{array}$} & \multicolumn{2}{|c|}{ Strongly agree } & \multicolumn{2}{|c|}{ Agree } & \multicolumn{2}{|c|}{$\begin{array}{c}\text { Disagree } \\
\text { less }\end{array}$} & \multicolumn{2}{|c|}{ Disagree } & \multicolumn{2}{|c|}{$\begin{array}{l}\text { Strongly } \\
\text { Disagree }\end{array}$} \\
\hline$(+)$ & $(-)$ & Frequency & $\%$ & Frequency & $\%$ & $(+)$ & $(-)$ & Frequency & $\%$ & Frequency & $\%$ \\
\hline 3 & & 22 & 68,8 & 9 & 28,1 & 1 & 3,1 & 0 & 0 & 0 & 0 \\
\hline 30 & & 11 & 34,4 & 16 & 50 & 4 & 12,5 & 0 & 0 & 1 & 3,1 \\
\hline To & & 33 & 103,2 & 25 & 78,1 & 5 & 15,6 & 0 & 0 & 1 & 3,1 \\
\hline Ave & age & & 51,60 & & 39,05 & & 7,8 & & 0 & & 1,55 \\
\hline
\end{tabular}

Based on the table above, it is known that the average student who strongly agreed was $51.60 \%$, students who agreed to $39.05 \%$, students who disagreed with $7.80 \%$, students who disagreed $0 \%$ and students who disagreed strongly disagree there is $1.55 \%$. The percentage of student learning motivation on the tenacity indicator can be seen in the following table:

Table 14. Percentage of Learning Motivation on Indicator 6

\begin{tabular}{|c|c|c|c|c|}
\hline Item Number & Score & Frequency & Total Score & Percentage $(\%)$ \\
\hline \multirow{5}{*}{3,30} & 5 & 33 & 165 & 58.7 \\
\hline & 4 & 25 & 100 & 35.6 \\
\hline & 3 & 5 & 15 & 5.3 \\
\hline & 2 & 0 & 0 & 0 \\
\hline & 1 & 1 & 1 & 0.4 \\
\hline \multicolumn{2}{|c|}{ Total } & 64 & 281 & 100 \\
\hline \multicolumn{2}{|c|}{ Highest Score } & \multicolumn{3}{|c|}{5} \\
\hline \multicolumn{2}{|c|}{ Number of Statement } & \multicolumn{3}{|c|}{2} \\
\hline \multicolumn{2}{|c|}{ Number of Respondents } & \multicolumn{3}{|c|}{32} \\
\hline \multicolumn{2}{|c|}{ Maximum Score } & \multicolumn{3}{|c|}{320} \\
\hline \multicolumn{2}{|c|}{ Percent Average } & \multicolumn{3}{|c|}{87,81} \\
\hline
\end{tabular}

In the table above, it is known that the average percentage of learning motivation on the tenacity indicator is $87.81 \%$. The percentage of each item of learning motivation on the resilience indicator can be seen in the following table:

Table 15. Recapitulation of Student Motivation in Online Learning Realistic Math Comic Video Based

\begin{tabular}{|c|c|c|c|c|c|c|}
\hline \multirow[b]{2}{*}{ Indicator } & \multicolumn{5}{|c|}{ Statements (\%) } & \multirow[b]{2}{*}{ Total } \\
\hline & $\begin{array}{c}\text { Strongly } \\
\text { Agree }\end{array}$ & Agree & $\begin{array}{c}\text { Disagree } \\
\text { Less }\end{array}$ & Disagree & $\begin{array}{l}\text { Strongly } \\
\text { Disagree }\end{array}$ & \\
\hline Responsible & 23,82 & 32,04 & 12,52 & 17,18 & 14,44 & 100 \\
\hline Trying to Excel & 35,64 & 37,50 & 13,76 & 11,86 & 1,24 & 100 \\
\hline Like challenges & 14,29 & 37,04 & 22,76 & 17,83 & 8,01 & 100 \\
\hline Independence & 21,08 & 50 & 12,50 & 9,40 & 7,02 & 100 \\
\hline Fortitude & 12,50 & 18,76 & 21,12 & 30,45 & 17,17 & 100 \\
\hline Tenacity & 51,60 & 39,05 & 7,8 & 0 & 1,55 & 100 \\
\hline
\end{tabular}


In addition, a recapitulation of the comparison of the percentage of student motivation in online learning based on realistic mathematics comic videos is also presented. The recapitulation results can be seen in the following table:

Table 16. Recapitulation of Comparison of Percentage of Learning Motivation in Online Learning Based on Realistic Mathematical Comic Videos

\begin{tabular}{|l|l|l|}
\hline Indicators & Percentage & Interpretation \\
\hline Responsible & 83,75 & Very high \\
\hline Trying to excel & 72,63 & High \\
\hline Like challenges & 71,07 & High \\
\hline Independence & 76,56 & High \\
\hline Fortitude & 68,75 & High \\
\hline Tenacity & 87,81 & Very high \\
\hline Average Score & 76,76 & High \\
\hline
\end{tabular}

\section{Conclusion}

Based on the results and discussion, it can be concluded that student motivation is high in online learning based on realistic mathematics comic videos. Therefore, it is hoped that teachers can design interesting learning videos, especially in online learning that can help increase student motivation. With the increase in learning motivation, it is hoped that student learning outcomes will also increase.

\section{Acknowledgments}

The author expresses his gratitude to the Directorate of Research and Community Service, Ministry of Research and Technology / National Innovation Research Agencybased on decree number: 8 / E1 / KPT / 2020 which has approved this research to be carried out and supports this research through the given research grant. The author also expresses his gratitude to the Head of the Region I Higher Education Service Institute and the Institute for Research and Community Service at the Catholic University of Santo Thomas based on the research contract number:216 / LL1 / PG / 2020 so that the author can complete this research properly and the results can be published in this paper. Hopefully this paper is useful for educators, researchers, and society for the advancement of science, especially in the field of education.

\section{References}

Azhar, A.A., and Sikumbang, A.T. (2018). Students' Trends in Islamic Communication Postgraduate in 2010-2016 State Islamic University of North Sumatera (UINSU). Budapest International Research and Critics Institute-Journal (BIRCI-Journal). P. 206214.

Beheshti, Mobina., Et. al. (2018). Characteristics of instructional videos. World Journal on Educational Technology: Current Issues. 10 (1). pp. 61-69.

Buzzetto-More, Nicole. (2015). Student Attitudes Towards The Integration Of YouTube In Online, Hybrid, And Web-Assisted Courses: An Examination Of The Impact Of Course Modality On Perception. MERLOT Journal of Online Learning and Teaching. 11 (1). pp. 55-73. 
Dwi Arinii, Fitri, Abdul Salim Choiri, and Sunardi. (2017). The Use of Comic As A Learning Aid to Improve Learning Interest of Slow Learner Student. European Journal of Special Education Research. 2 (1). pp. 71-78.

Georgaka, Angeliki Deligianni and Ourania Pouroutidi. (2016). Creating Digital Comics to Motivate Young Learners to Write: A Case Study. Research Papers in Language Teaching and Learning. 7 (1). Pp. 233-263.

Hadijah, Sitti. (2016). Teaching By Using Video: Ways to Make It More Meaningful in EFL Classrooms. Proceedings of the Fourth International Seminar on English Language and Teaching (ISELT-4). pp. 307-315.

Lestaria, Laras and Edy Surya. (2017). The Effectiveness of Realistic Mathematics Education Approach on Ability of Students' Mathematical Concept Understanding. International Journal of Sciences: Basic and Applied Research (IJSBAR). 34 (1). pp. 91-100.

Lestari, Witri and Yhohan Ady Chandra. (2018). Development of Mathematical Comic-Strip Application as a Mobile Learning Media-Based Learning. Journal of Mathematics Education (JME). 3 (2). pp. 54-59.

Mendoza, Gia Lenn L., Lawrence C. Caranto, and Juan Jose T. David. (2015). Effectiveness of Video Presentation to Students' Learning. International Journal of Nursing Science. 5 (2): 81-86.

Nopriani Lubis, Jumaita, Asmin Panjaitan, Edy Surya, and Edi Syahputra. (2017). Analysis Mathematical Problem Solving Skills of Student of the Grade VIII-2 Junior High School Bilah Hulu Labuhan Batu. International Journal of Novel Research in Education and Learning. 4 (2), pp. 131-137.

Özdemira, Emine and Devrim Üzela. (2012). Student Opinions On Teaching Based On Mathematical Modeling. Procedia - Social and Behavioral Sciences. 55. pp. 12071214.

Panhuizen, Marja Van den Heuvel and Paul Drijvers. (2014). Realistic Mathematics Education. Encyclopedia of Mathematics Education. pp. 521-534.

Ulya, H., Kartono, and A. Retnoningsih. (2014). Analysis of Mathematics Problem Solving Ability of Junior High School Students Viewed From Students' Cognitive Style. International Journal of Education and Research. 2 (10). pp. 577-582.

Yousef, Ahmed Mohamed Fahmy, Mohamed Amine Chatti, and Ulrik Schroeder. (2014). The State of Video-Based Learning: A Review and Future Perspectives. International Journal on Advances in Life Sciences. 6 (3 \& 4). pp. 122-135.

Muhammad Thosimin. (2014). Pengaruh Intensitas Mengikuti Dzikir Burdah Terhadap Kesehatan Mental Santri Pondok Pesantren Al-Fithrah Meteseh. Skripsi, IAIN Walisongo. Diakses dari eprints.walisongo.ac.id.

Parsudi Suparlan. (1980). Culture and Fertility: The Case of Indonesia. Singapore: The Institute of Southeast Asian Study.

R. Seokmono. (1973). Sejarah Kebudayaan Indonesia 2. Yogyakarta: Kanisius.

Rifyal Ka'bah. (1999). Dzikir dan Do'a dalam Al-Quran. Jakarta: Paramadani.

Simorangkir, F.M.A., and Sembiring, R.K.B. (2018). Effectiveness of Helped Mathematical Learning Media of Lectora Inspire on The Number Sense Ability of Fifth Grade Students of Elementary School in Substrate Materials. Budapest International Research and Critics Institute-Journal (BIRCI-Journal). P. 352-358

Sitorus, H.V., et al (2019). The Effect of Learning Strategy and Thinking Ability on The Students' Learning Outcomes in Economics Subject of XI Social Students in Senior High School State 1 in Pematang Siantar. Budapest International Research and Critics in Linguistics and Education (BirLE) Journal. P. 451-460. 
Sari, A. F., Rusnaini, Rejekiningsih, T. (2019). The Concept of Tolerance among Religious Community by the Religious Activists of Interfaith Community and Pantura Belief (Tali Akrap). Budapest International Research and Critics Institute-Journal (BIRCIJournal), 132-142.

Sulasman, M. Hum. (2014). Metodologi Penelitian Sejarah; Teori, Metode, dan Contoh Aplikasi. (Bandung: CV. Pustaka Setia)

Ulin Nuha. (2015). Shalawat Burdah. Jakarta: Mutiara Media. 